\title{
Survival factors regulating ovarian apoptosis - dependence on follicle differentiation
}

\author{
Emilia Markström, Eva Ch. Svensson, Ruijin Shao, \\ Bodil Svanberg and Håkan Billig*
}

\author{
Department of Physiology, Göteborg University, PO Box 434, SE-405 30 Göteborg, Sweden
}

\begin{abstract}
Only a minute fraction of the ovarian follicles present in a fetal ovary will complete the path to ovulation. Most of the follicles will undergo atresia, a hormonally controlled apoptotic process. Apoptosis occurs at each stage of follicular development and there is a marked reduction in the number of follicles present at birth. Stage-dependent mechanisms of follicle survival can be postulated to achieve co-ordinated development, leading to ovulation of a small fraction of follicles. Indeed, hormone and growth factor regulation of follicular atresia is stage-specific. This short review considers the factors that promote survival of ovarian follicles throughout development, including endocrine, locally produced and intracellular mediators, as exemplified mainly by follicular development in rodents. In primordial follicles, oocyte apoptosis is considered to be the cause of subsequent follicle degeneration. In slow-growing preantral follicles, FSH is not a survival factor, but some locally produced growth factors are. Progression to the antral follicle stage is probably the most critical stage of follicle development in vivo, and $\mathrm{FSH}$ is a major survival factor at this stage. In addition, insulin-like growth factor I and interleukin $1 \beta$ are potent survival factors for cultured rat follicles at the antral stage. Preovulatory follicles express receptors for $\mathrm{LH}$, and both of the gonadotrophins are survival factors at this stage. Relatively little is known about the period between the LH surge and ovulation; however, it has been suggested that at this stage progesterone acts as a survival factor.
\end{abstract}

The human fetal ovaries contain millions of germ cells: the maximum number is observed at month 5 of pregnancy $\left(6.8 \times 10^{6}\right.$ germ cells $)$. Degeneration of germ cells occurs before formation of the ovarian follicles and thus regulates the number of primordial follicles present within the ovaries. The number of germ cells decreases markedly up to birth, at which stage the number of germ cells in the primordial follicles is less than $20 \%$ of the maximum number (Baker, 1963).

More than $99.9 \%$ of the ovarian follicles present at birth never reach ovulation. The most common fate of follicles is to undergo atresia, which is mediated by a highly organized type of cell death called apoptosis or programmed cell death (Hsueh et al., 1994; Billig et al., 1996; Kaipia and Hsueh, 1997). The reduction of the large number of growing follicles to a single ovulatory follicle is achieved primarily by cell death of granulosa cells (Hsueh et al., 1994; Reynaud and Driancourt, 2000).

Individual mammalian follicles consist of a central oocyte surrounded by somatic granulosa cell layers and outer layers of somatic theca cells. The maturation of ovarian follicles involves several sequential stages: initiation of growth of

*Correspondence

Email: hakan.billig@fysiologi.gu.se primordial follicles in the resting pool, growth of the follicles, selection of a dominant follicle, ovulation and, finally, luteinization. The initiation of growth of resting primordial follicles, designated initial recruitment (McGee and Hsueh, 2000), is followed by growth, differentiation and atresia. When the follicle acquires an antral cavity, it becomes dependent on hormonal support from FSH. During each reproductive cycle, increasing FSH concentrations recruit growing antral follicles. The term 'cyclic recruitment' has been proposed to describe this rescue from degeneration (McGee and Hsueh, 2000). At the last stage in follicular development, the endogenous LH surge induces ovulation and formation of the corpus luteum. During the growth and development of follicles, atresia occurs at every stage of follicular development (Gougeon, 1986), except the final stage. At the final stage, the number of corpora lutea is equal to the number of follicles that respond to the LH surge, implying decreased sensitivity to apoptosis.

Follicular atresia is regulated by endocrine factors, such as FSH and $\mathrm{LH}$, and by paracrine factors, including insulinlike growth factor I (IGF-I), epidermal growth factor (EGF), basic fibroblast growth factor (bFGF), activin and interleukin $1 \beta$ (IL-1 $\beta)$. Atretogenic factors include tumour necrosis factor $\alpha$ (TNF- $\alpha$ ), GnRH, androgens, IL- 6 and free radicals (Kaipia and Hsueh, 1997). Granulosa cell apoptosis 
is an active cellular event that is dependent on transcription and protein synthesis, as incubation in the presence of the transcription inhibitor actinomycin D or the translation inhibitor cyclohexamide decreases the rate of spontaneous apoptosis is a dose-dependent manner (Svanberg and Billig, 1999).

\section{Models for ovarian apoptosis}

A range of stimuli can affect whether a cell will undergo atresia. In the ovary, there are several specific regulators of apoptosis, including hormones, growth factors and cytokines (Fig. 1). Investigation of ovarian apoptosis is problematic as the process concludes with phagocytosis of the apoptotic cell by surrounding cells, leaving no detectable traces for investigation. Furthermore, in the ovary, different factors regulate apoptosis in follicle populations of different developmental stages, necessitating models in which homogeneous cohorts of follicles can be isolated at specific stages.

Many models for studying follicular atresia have taken advantage of the fact that isolated follicles or granulosa cells undergo spontaneous apoptosis when cultured in the absence of serum (Tilly et al., 1992). Addition of survival or pro-apoptotic factors to the incubation medium can affect the rate of spontaneous apoptosis. Several rodent models have also been developed to isolate follicles at specific stages of development. For instance, administration of diethylstilboestrol implants to hypophysectomized rats provides an opportunity to study preantral and early antral follicles (Billig et al., 1993). Further differentiation can be achieved by sequential stimulation of the FSH and $\mathrm{LH}$ receptors of immature rats. In humans, the source of material is most often periovulatory granulosa cells collected from women undergoing oocyte aspiration before in vitro fertilization.

\section{Mechanisms of apoptosis}

Once the decision to die has been made, the execution of the apoptotic death requires co-ordinated activation and propagation of several sub-programmes (Hengartner, 2000). Two important families of regulators of the apoptotic process are the caspase family and the Bcl-2 family (Fig. 1). Caspases are considered the executioners of the apoptotic pathway (Hengartner, 2000) and function as proteases, cleaving after an aspartic acid residue. There are at least three mechanisms for caspase activation: (i) processing by an upstream caspase; (ii) association with co-factors; and (iii) cleavage induced by a high local concentration of caspases associated with activated death receptors. More than 100 substrates are known to be cleaved by caspases, including lamins, required for nuclear shrinking and budding, and cytoskeletal proteins, such as fodrin and gelsolin, causing loss of overall cell shape (Hengartner, 2000). An important function of the caspases is to activate caspase-activated DNase (CAD), the endonuclease responsible for internucleosomal DNA fragmentation, one of the most frequently used hallmarks of apoptosis. CAD and its inhibitory subunit, inhibitor of caspase-activated DNase (ICAD), are constantly expressed in the cells. Caspase-mediated cleavage of the inhibitory subunit results in release and activation of the endonuclease.

The Bcl-2 family of apoptotic regulators comprises both anti-apoptotic members, such as $\mathrm{BCl}-2$ and $\mathrm{BCl}-\mathrm{X}_{\mathrm{L}}$, and proapoptotic members, including $\mathrm{Bax}, \mathrm{Bid}, \mathrm{Bik}, \mathrm{BOD}$ and $\mathrm{Bcl}$ $\mathrm{X}_{\mathrm{S}}$. Members of the $\mathrm{Bcl}-2$ family can both homodimerize and heterodimerize with several other family members, thereby regulating activity of one another. The essential function of the $\mathrm{Bcl}-2$ family appears to be to regulate release of pro-apoptotic factors, in particular cytochrome $c$, from the mitochondrion into the cytosol (Antonsson and Martinou, 2000). Many members of the $\mathrm{BCl}-2$ family have been isolated in the ovary, including BAD, Mcl- 1 and Bok (Hsu and Hsueh, 2000).

The mitochondrion is a crucial structure in the apoptotic machinery, harbouring several pro-apoptotic factors that are released into the cytoplasm upon a specific signal (Fig. 1). One of these factors is cytochrome $c$, which is required for caspase 9 activation in the cytosol. How cytochrome $c$ crosses the outer mitochondrial membrane remains to be elucidated, but the members of the $\mathrm{Bcl}-2$ family are involved closely in the regulation of this process. Release of cytochrome $c$ is an almost universal event during apoptotic cell death. However, in some cases it is a very late event, such as in apoptosis induced by death receptors, in which the mitochondrial pathway is often bypassed and cytochrome $c$ is released as a result of caspase activation (Scaffidi et al., 1998). In addition to cytochrome $c$, other pro-apoptotic factors are stored in the mitochondria and are released upon induction of apoptosis. Examples include apoptosis-inducing factor (AIF) and several pro-caspases.

After apoptotic death of a cell, the cellular remains are removed. Exposure of phosphatidylserine on the outer cell membrane is one signalling mechanism that occurs in apoptotic cells (Fig. 1). In the ovary, scavenger receptor class B type I (SR-BI) on theca cells mediates recognition and binding of apoptotic granulosa cells expressing phosphatidylserine on the cell surface (Svensson et al., 1999).

\section{Dependence on stage of follicle differentiation}

Follicular atresia is a hormonally regulated process, and different factors are affecting the decision to die at different stages of ovarian follicle development. Some of the factors that promote survival during the growth and differentiation of follicles are summarized (Fig. 2). Although a number of locally produced growth factors affect follicle cell survival, the main physiological regulators of ovarian follicle survival are the gonadotrophins. Most, if not all, of the factors reported in published studies as inhibitors of follicle atresia are regulated by $\mathrm{FSH}$ and $\mathrm{LH}$. When the growing follicles reach the antral stage, they express receptors for $\mathrm{FSH}$ and become dependent on FSH stimulation. Sufficient FSH 


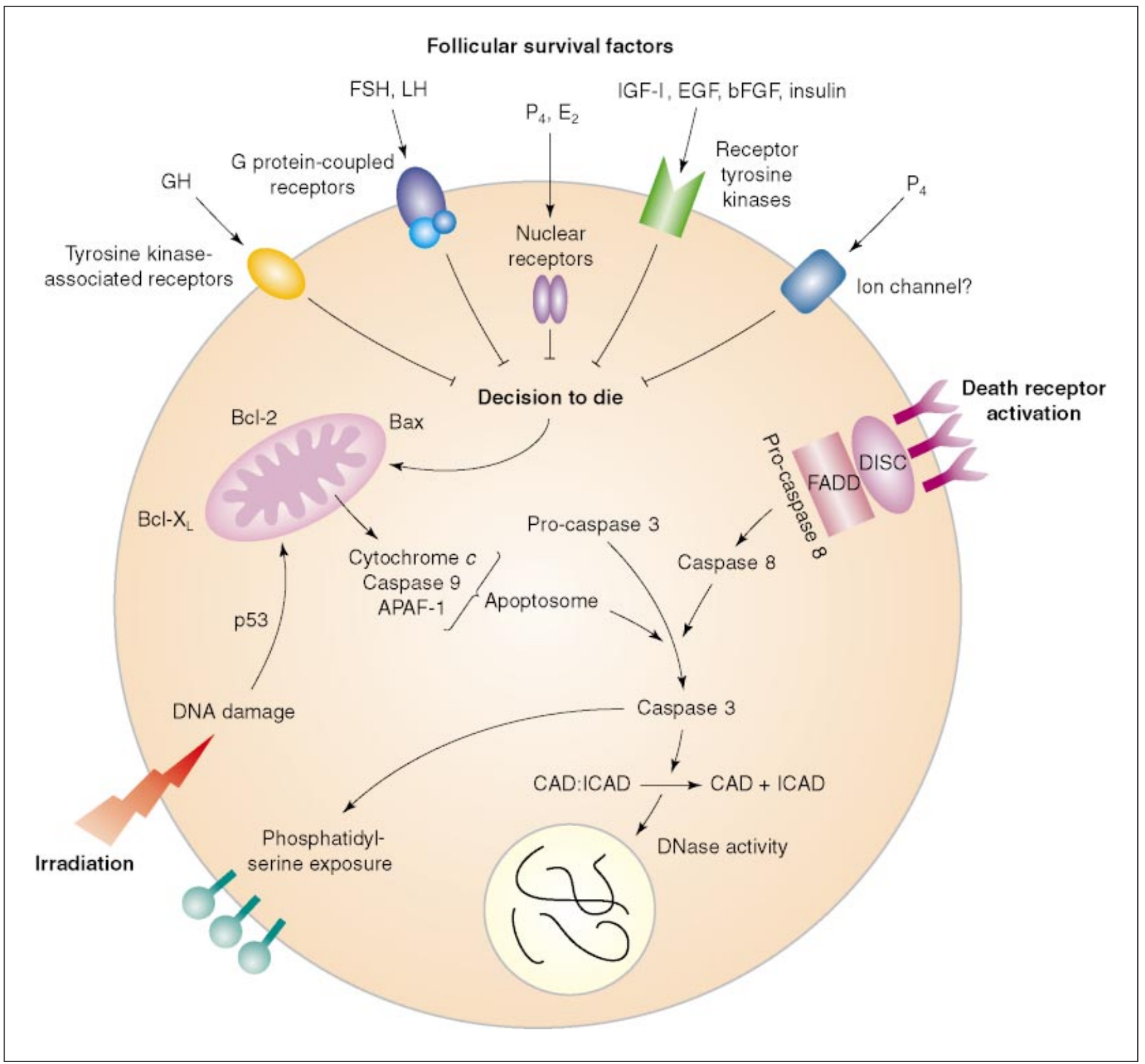

Fig. 1. Schematic overview of the apoptotic process in follicular granulosa cells. A range of hormones and locally produced factors regulates the 'decision to die' by way of their receptors. Examples of survival factors include the gonadotrophins FSH and LH, the steroids progesterone $\left(\mathrm{P}_{4}\right)$ and oestrogen $\left(\mathrm{E}_{2}\right)$, and other factors including growth hormone $(\mathrm{GH})$, insulin-like growth factor I (IGF-I), epidermal growth factor (EGF), basic fibroblast growth factor (bFGF) and insulin. The signalling of these factors is mediated via a range of different types of receptor. Execution of the apoptotic programme converges in the mitochondria, in which pro- and anti-apoptotic members of the $\mathrm{Bcl}-2$ family interact at the surface. Excess pro-apoptotic activity causes release of an array of molecules from the mitochondrial compartment. One of the principal molecules is cytochrome $c$, which associates with apoptotic protease-activating factor 1 (APAF-1) and pro-caspase 9 to form the apoptosome complex. This complex subsequently activates downstream caspases, such as caspase 3. Downstream of caspase 3, the apoptotic programme branches into a multitude of sub-programmes, among which is exposure of phosphatidylserine on the cell surface. Another effect of caspase activation is cleavage of inhibitor of caspase-activates DNase (ICAD) resulting in release of caspase-activated DNase (CAD), the endonuclease responsible for internucleosomal DNA fragmentation. Two other pathways for induction of apoptosis are also represented. One pathway is DNA damage caused by, for example, irradiation, which initiates the apoptotic process via p53. The second pathway is the death receptor pathway, which has been characterized mainly in immune cells. Binding of ligand to these receptors (for example CD95/Fas, tumour necrosis factor receptor I) causes receptor clustering and formation of a death-inducing signalling complex (DISC). This complex recruits multiple copies of pro-caspase 8, via the adaptor molecule Fas-associated death domain protein (FADD), resulting in activation of caspase 8. 


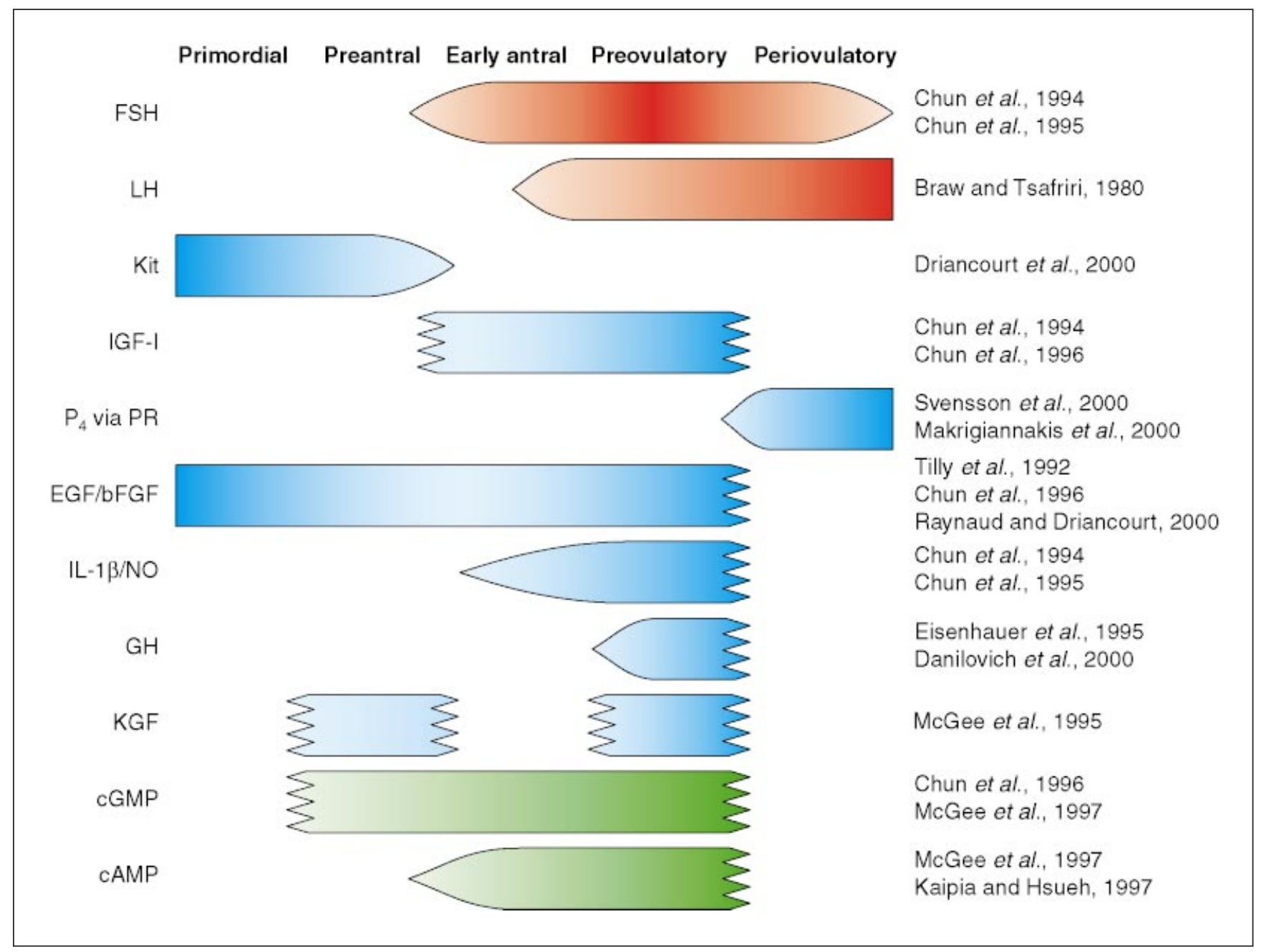

Fig. 2. Examples of factors that regulate stage-dependent survival of ovarian follicles: gonadotrophins (red); locally produced survival factors (blue); and intracellular mediators (green). Jagged ends indicate that studies have not been presented regarding earlier or later developmental stages. Examples of relevant references are provided. bFGF: basic fibroblast growth factor; EGF: epidermal growth factor; $\mathrm{GH}$ : growth hormone IGF-I: insulin-like growth factor; IL-1 $\beta$ : interleukin 1 $\beta$; KGF: keratinocyte growth factor; NO: nitric oxide; $\mathrm{P}_{4}$ : progesterone; PR: progesterone receptor.

concentrations are critical for survival of follicles that have differentiated to the antral stage or beyond. During each reproductive cycle, increasing $\mathrm{FSH}$ concentrations rescue developing follicles, that is, there is cyclic recruitment. $\mathrm{LH}$ is important for follicles approaching ovulation and expressing the $\mathrm{LH}$ receptor. Inhibition of the LH surge results in massive atresia in rats (Braw and Tsafriri, 1980). In the adult human ovary, the degree of atresia has been estimated to be highest in antral follicles $>5 \mathrm{~mm}$ in diameter (Gougeon, 1986).

The differentiation-dependent regulation that occurs throughout follicular development has to be acknowledged to understand the finely tuned balance of follicle growth and atresia.

\section{Primordial follicles}

In primordial follicles, it is likely that oocyte apoptosis is responsible for subsequent follicular degeneration. Oocyte apoptosis has been reviewed recently by Morita and Tilly (1999) and Reynaud and Driancourt (2000), who described the importance of, for instance, Kit-Kit ligand interaction and the growth factors EGF and bFGF in rodents. It has been reported that Kit-Kit ligand interaction is important for survival of primordial follicles in fetal as well as postnatal ovaries. Interaction probably prevents degeneration of follicles by rescuing the oocyte (Driancourt et al., 2000). Another oocyte-derived factor that is important for survival of small follicles is growth and differentiation factor 9 (GDF- 
9). In mice lacking GDF-9, follicles do not develop beyond the primary or early secondary stage (Dong et al., 1996).

The aryl hydrocarbon receptor (AhR) may be important in regulating the size of the pool of primordial germ cells. Ovaries collected from fetal mice and cultured in vitro show a high rate of oocyte apoptosis. The number of non-apoptotic oocytes after culture of fetal ovaries from AhR-deficient mice was almost three times higher than that in cultured fetal ovaries from wild-type mice (Robles et al., 2000). However, at present, the endogenous ligand for $A h R$ is unknown.

\section{Preantral follicles}

Preantral follicles are characterized by slow growth, and there are distinct differences between human and rat follicles at this stage. Human follicles reach the preantral stage several months before ovulation, whereas rat follicles become preantral only a few days before ovulation. Thus, although they are at the same morphological stage, there may be developmental differences between preantral rat and human follicles (McGee, 2000). Relatively little is known about regulation of survival of preantral follicles in rodents and humans compared with understanding of survival at later stages of development.

When isolated preantral follicles from 12-14-day-old rats are cultured in serum-free medium, there is a spontaneous onset of apoptosis in the granulosa cells, similar to that seen in preovulatory follicles. At this early stage of differentiation, FSH and its downstream mediator cAMP have no effect on apoptosis in cultured rat follicles (McGee et al., 1997a). However, this lack of effect is not due to lack of $\mathrm{FSH}$ receptors, as $\mathrm{FSH}$ has the ability to enhance expression of steroidogenic enzymes in preantral follicles (Dunkel et al., 1994; Rannikki et al., 1995). In contrast, both FSH and $\mathrm{LH}$ receptor stimulation are important for development of preantral rat follicles in vivo (McGee et al., 1997b). This finding indicates that gonadotrophins do not act directly on preantral follicles, but that the effect is mediated via other gonadotrophin-sensitive cells, such as cells in follicles at a later stage of differentiation.

Locally produced survival factors for preantral follicles include keratinocyte growth factor (KGF). KGF is produced by theca cells in the ovary, and receptors are present in granulosa cells. In cultured preantral rat follicles, KGF suppresses apoptosis and also promotes growth and differentiation (McGee et al., 1999). Similarly, FGF suppresses apoptosis in cultured preantral rat follicles (McGee et al., 1999). Other locally produced survival factors are oestrogens, which cause a decrease in the rate of granulosa cell apoptosis in preantral follicles in vivo in hypophysectomized rats. This effect is inhibited by treatment with testosterone (Billig et al., 1993).

Intracellular mediators for survival of preantral follicles include cGMP, but not CAMP. It has been reported that treatment of isolated preantral rat follicles with a cGMP analogue reduces the degree of apoptosis by as much as 75\% (McGee et al., 1997a).
Dietary ascorbic acid (vitamin C) also affects fertility in humans. Murray et al. (2001) reported that addition of ascorbic acid to mouse preantral follicles cultured in vitro decreases the rate of apoptosis and increases the percentage of follicles that maintain basement membrane integrity.

Factors that promote growth of ovarian follicles, for example FSH and bFGF, also inhibit apoptosis, although there are some exceptions. For instance, Müllerian inhibitory substance (MIS) promotes the growth of preantral rat follicles without affecting granulosa cell apoptosis or differentiation (McGee et al., 2001).

\section{Early antral follicles}

During the normal reproductive cycle in humans and rodents, the early antral stage is the most critical stage of follicle development. Early antral follicles express receptors for $\mathrm{FSH}$ and become dependent on FSH stimulation for survival. Owing to the lack of FSH support, many follicles never progress beyond this point in development (see Hirshfield, 1991).

In isolated early antral follicles from rats, FSH is the most important survival factor. FSH is able to suppress apoptosis by up to $60 \%$. The effect was partially reversed by addition of the IGF binding protein IGFBP-3, indicating a mediatory role of IGF-I. In contrast, stimulation of $\mathrm{LH}$ receptors has a limited effect on survival of rat follicles at this stage (Chun et al., 1996).

Locally produced factors that are important for survival of isolated early antral rat follicles include IGF-I, EGF, bFGF, activin and the cytokine IL-1 $\beta$. Growth hormone $(\mathrm{GH})$ is unable to suppress apoptosis in cultured early antral follicles, despite inducing increased expression of IGF-I mRNA (Chun et al., 1996). However, several of these locally produced factors are more potent as survival factors in later stages of follicle development. For instance, IL-1 $\beta$ is threefold more effective in preventing apoptosis in preovulatory than in early antral follicles. Since IL-1 $\beta$ probably mediates its effects via receptors on theca cells, the higher degree of suppression in preovulatory follicles might be the result of the presence of more differentiated theca cells at that developmental stage (Chun et al., 1996). At the early antral stage, there is a differential effectiveness of the hormones and growth factors that regulate survival of cultured rat follicles: FSH > IGF-I, IL-1 $\beta>$ LH, EGF, bFGF, activin $>>$ GH (Chun et al., 1996). As in preantral follicles, oestrogens are important for survival of early antral follicles in vivo in rats (Billig et al., 1993). However, there are no reports that demonstrate that oestrogens affect survival of cultured follicles or granulosa cells.

\section{Preovulatory follicles}

At the preovulatory stage of development ovarian follicles express $\mathrm{LH}$ receptors and are able to respond to the impending LH surge. Both FSH and LH suppress the degree of apoptosis in isolated preovulatory rat follicles (Chun et al., 1994). Studies of cultured preovulatory rat follicles have 
shown that the suppression of apoptosis observed after treatment with gonadotrophins may be partially mediated by endogenous IGF-I (Chun et al., 1994). At least three lines of evidence support this hypothesis (see Chun et al., 1994): (i) addition of IGFBP-3 results in a dose-dependent decrease in the apoptosis suppressive effect of $\mathrm{LH}$ receptor stimulation; (ii) concentrations of IGFBP-4 and -5 are higher in atretic human follicles than in healthy human follicles; and (iii) $\mathrm{LH}$ receptor stimulation results in an increase in IGF-I mRNA content in cultured preovulatory rat follicles. However, IGF-I has no effect in isolated granulosa cells from preovulatory follicles (Tilly et al., 1992), indicating interaction with other follicular cells. The cytokine IL-1 $\beta$ also mediates part of the apoptosis suppressive effects of gonadotrophins in rats. Addition of an IL-1 $\beta$ receptor antagonist partially decreases the effect of gonadotrophins (Chun et al., 1995). Furthermore, IL-1 $\beta$ alone suppresses apoptosis in cultured preovulatory follicles, and simultaneous addition of IL-1 $\beta$ and an IL-1 $\beta$ antagonist reverses the effect. The effect of IL-1 $\beta$ is probably mediated via generation of NO and cGMP (Chun et al., 1995).

In rat preovulatory follicles and isolated granulosa cells the locally produced survival factors EGF and bFGF suppress apoptosis as effectively as do gonadotrophins (Tilly et al., 1992). This effect is mediated through the tyrosine kinase pathway, as addition of the tyrosine kinase inhibitor genistein inhibits the effect of EGF and bFGF. The EGF receptor is upregulated by gonadotrophins (Fujinaga et al., 1994), which probably explains why there is no effect or only a small effect on apoptosis in preantral and early antral rat follicles (Tilly et al., 1992; McGee et al., 1997a). Transforming growth factor $\alpha$ (TGF- $\alpha)$ is a structural and functional homologue of EGF that shares the same cell membrane receptor. TGF- $\alpha$ mimics the effects of EGF in isolated preovulatory rat follicles (Tilly et al., 1992). KGF, a member of the FGF family, is also anti-apoptotic when added to cultured preovulatory rat follicles (McGee et al., 1999).

Insulin is another survival factor for cultured preovulatory rat follicles. It has been reported that insulin decreases sensitivity to apoptosis in vitro (Chun et al., 1994). This effect is probably mediated via the IGF-I receptor, and IGF-I has a stronger anti-apoptotic effect than does insulin. Insulin has no effect on isolated preovulatory rat granulosa cells (Tilly et al., 1992), indicating the involvement of other ovarian cells. GH is also able to suppress apoptosis in cultured preovulatory rat follicles. As the effect of $\mathrm{GH}$ is inhibited by addition of IGFBP-3, it is probably mediated by IGF-I (Eisenhauer et al., 1995). In addition, it has been reported that mice overexpressing bovine $\mathrm{GH}$ have an increased number of healthy preovulatory follicles and a smaller percentage of preovulatory follicles undergoing a high degree of apoptosis compared with non-transgenic littermates (Danilovich et al., 2000). This effect is in contrast to the situation at the earlier developmental stages, in which GH has no effect on apoptosis (Chun et al., 1996).

Intracellular mediators of preovulatory follicle survival include cAMP and cGMP. However, stimulation of protein kinase $\mathrm{A}$ or $\mathrm{C}$ signalling pathways in isolated rat granulosa cells has no effect on apoptosis (Tilly et al., 1992).

\section{Periovulatory follicles}

Follicles that survive to the periovulatory stage are dependent on the endogenous LH surge. Inhibition of the LH surge by hypophysectomy or pentobarbital treatment causes the follicles to degenerate (Talbert et al., 1951; Braw and Tsafriri, 1980). The decrease in spontaneous apoptosis observed in isolated preovulatory rat follicles treated with hCG to stimulate the LH receptor may be mediated, at least in part, by endogenous production of pituitary adenylate cyclase-activating polypeptide (PACAP). LH-induced suppression of follicular apoptosis is partly inhibited by cotreatment with a PACAP antagonist (Lee et al., 1999).

After the LH surge, the follicles are less susceptible to atresia than are follicles at earlier stages, as shown by decreased sensitivity to apoptosis in vitro (Svensson et al., 2000). The mechanism for this reduced sensitivity has not been studied in detail; however, in granulosa cells isolated from periovulatory follicles in rats (Svensson et al., 2000) and humans (Makrigiannakis et al., 2000), progesterone functions as a regulator of apoptosis via its nuclear receptor. Effects of progesterone that are not mediated by its nuclear receptor have also been suggested. Progesterone has been attributed an apoptosis-inhibiting effect in immature and preovulatory (but not $\mathrm{LH}$ receptor-stimulated) rat granulosa cells via a GABA receptor-like receptor (Peluso and Pappalardo, 1998). However, addition of GABA receptor antagonists (picrotoxin and bicuculline) and the GABA agonist muscimol to isolated granulosa cells from rat periovulatory follicles did not influence the degree of apoptosis (Svensson et al., 2000).

Expression of the nuclear progesterone receptor is induced shortly after the LH surge in both rat and human granulosa cells, coinciding with the apoptosis suppressive effects of progesterone. In rat granulosa cells expression of progesterone receptors is transient (Park and Mayo, 1991; Natraj and Richards, 1993), whereas in humans expression of progesterone receptors is prolonged, and the progesterone receptor is also present in the corpus luteum (Press and Greene, 1988; Iwai et al., 1990). Mice lacking both isoforms of the progesterone receptor (A and $\mathrm{B}$ ) are anovulatory, supporting the contention that progesterone has direct effects in the ovary (Lydon et al., 1995, 1996). Mice lacking only the A isoform of the receptor show decreased ovulation after stimulation (Mulac-Jericevic et al., 2000), whereas mice lacking only the B isoform are fertile and produce normal-sized litters (Mulac-Jericevic et al., 2001). It has also been reported that addition of progestins augments gonadotrophin-stimulated progesterone production by cultured rat granulosa cells (Fanjul et al., 1983). Recently, genes that are regulated by the progesterone receptor have been identified in granulosa cells during the periovulatory interval, including PACAP and its receptor 
PAC $_{1}$ (Ko et al., 1999; Ko and Park-Sarge, 2000) and the proteases ADAMTS-1 (a disintegrin and metalloproteinase with thrombospondin-like motifs) and cathepsin L (Robker et al., 2000).

As the progesterone receptor-progesterone complex acts as a transcription factor and inhibition of progesterone increases apoptosis, further studies of progesterone receptorregulated gene expression will probably identify pathways that are important for follicle cell survival.

\section{Conclusions}

Follicular development, characterized by high rates of proliferation and apoptosis, is a tightly regulated process, which is dependent on a balance between local ovarian growth factors and circulating hormones. However, the diminishing number of follicles in each developmental stage indicates that the control of follicular survival or atresia is not the same at each stage. All follicles are not alike: both the susceptibility to apoptosis and the regulators of follicle survival change during the different stages of development (Fig. 2). Increased understanding of the sequential regulatory events of follicle development will aid development of new contraceptives and new methods for increasing the female reproductive lifespan and will lead to improvements in culture methods for oocytes for in vitro fertilization.

\section{References}

Key references are identified by asterisks.

Antonsson B and Martinou JC (2000) The Bcl-2 protein family Experimental Cell Research 256 50-57

Baker TG (1963) A quantitative and cytological study of germ cells in human ovaries Proceedings of the Royal Society of London - Biological Sciences 158 417-433

Billig H, Furuta I and Hsueh AJ (1993) Estrogens inhibit and androgens enhance ovarian granulosa cell apoptosis Endocrinology 133 2204-2212

Billig H, Chun SY, Eisenhauer K and Hsueh AJ (1996) Gonadal cell apoptosis: hormone-regulated cell demise Human Reproduction Update 2 103-117

Braw RH and Tsafriri A (1980) Follicles explanted from pentobarbitonetreated rats provide a model for atresia Journal of Reproduction and Fertility $\mathbf{5 9}$ 259-265

Chun SY, Billig H, Tilly JL, Furuta I, Tsafriri A and Hsueh AJ (1994) Gonadotropin suppression of apoptosis in cultured preovulatory follicles: mediatory role of endogenous insulin-like growth factor I Endocrinology 135 1845-1853

Chun SY, Eisenhauer KM, Kubo M and Hsueh AJ (1995) Interleukin-1 beta suppresses apoptosis in rat ovarian follicles by increasing nitric oxide production Endocrinology 136 3120-3127

Chun SY, Eisenhauer KM, Minami S, Billig H, Perlas E and Hsueh AJ (1996) Hormonal regulation of apoptosis in early antral follicles: folliclestimulating hormone as a major survival factor Endocrinology 137 1447-1456

Danilovich NA, Bartke A and Winters TA (2000) Ovarian follicle apoptosis in bovine growth hormone transgenic mice Biology of Reproduction $\mathbf{6 2}$ 103-107

Dong J, Albertini DF, Nishimori K, Kumar TR, Lu N and Matzuk MM (1996) Growth differentiation factor-9 is required during early ovarian folliculogenesis Nature $\mathbf{3 8 3}$ 531-535

Driancourt MA, Reynaud K, Cortvrindt R and Smitz J (2000) Roles of KIT and KIT LIGAND in ovarian function Reviews of Reproduction $\mathbf{5}$ 143-152
Dunkel L, Tilly JL, Shikone T, Nishimori K and Hsueh AJ (1994) Folliclestimulating hormone receptor expression in the rat ovary: increases during prepubertal development and regulation by the opposing actions of transforming growth factors beta and alpha Biology of Reproduction 50 940-948

Eisenhauer KM, Chun SY, Billig H and Hsueh AJ (1995) Growth hormone suppression of apoptosis in preovulatory rat follicles and partial neutralization by insulin-like growth factor binding protein Biology of Reproduction 53 13-20

Fanjul LF, Ruiz de Galarreta CM and Hsueh AJ (1983) Progestin augmentation of gonadotropin-stimulated progesterone production by cultured rat granulosa cells Endocrinology 112 405-407

Fujinaga H, Yamoto M, Shikone T and Nakano R (1994) FSH and LH upregulate epidermal growth factor receptors in rat granulosa cells Journal of Endocrinology 140 171-177

Gougeon A (1986) Dynamics of follicular growth in the human: a model from preliminary results Human Reproduction 1 81-87

*Hengartner MO (2000) The biochemistry of apoptosis Nature 407 770-776

Hirshfield AN (1991) Development of follicles in the mammalian ovary International Review of Cytology 124 43-101

*Hsu SY and Hsueh AJ (2000) Tissue-specific Bcl-2 protein partners in apoptosis: an ovarian paradigm Physiological Reviews 80 593-614

*Hsueh AJ, Billig H and Tsafriri A (1994) Ovarian follicle atresia: a hormonally controlled apoptotic process Endocrine Reviews 15 $707-724$

Iwai T, Nanbu Y, Iwai M, Taii S, Fujii S and Mori T (1990) Immunohistochemical localization of oestrogen receptors and progesterone receptors in the human ovary throughout the menstrual cycle Virchows Archiv A Pathological Anatomy and Histopathology 417 369-375

Kaipia A and Hsueh AJ (1997) Regulation of ovarian follicle atresia Annual Review of Physiology 59 349-363

Ko C and Park-Sarge OK (2000) Progesterone receptor activation mediates LH-induced type-I pituitary adenylate cyclase activating polypeptide receptor (PAC(1)) gene expression in rat granulosa cells Biochemical and Biophysical Research Communications 277 270-279

Ko C, In YH and Park-Sarge OK (1999) Role of progesterone receptor activation in pituitary adenylate cyclase activating polypeptide gene expression in rat ovary Endocrinology 140 5185-5194

Lee J, Park HJ, Choi HS, Kwon HB, Arimura A, Lee BJ, Choi WS and Chun SY (1999) Gonadotropin stimulation of pituitary adenylate cyclaseactivating polypeptide (PACAP) messenger ribonucleic acid in the rat ovary and the role of PACAP as a follicle survival factor Endocrinology 140 818-826

Lydon JP, DeMayo FJ, Funk CR et al. (1995) Mice lacking progesterone receptor exhibit pleiotropic reproductive abnormalities Genes and Development 9 2266-2278

Lydon JP, DeMayo FJ, Conneely OM and O'Malley BW (1996) Reproductive phenotypes of the progesterone receptor null mutant mouse Journal of Steroid Biochemistry and Molecular Biology 56 67-77

McGee EA (2000) The regulation of apoptosis in preantral ovarian follicles Biological Signals and Receptors 9 81-86

McGee EA and Hsueh AJ (2000) Initial and cyclic recruitment of ovarian follicles Endocrine Reviews 21 200-214

McGee E, Spears N, Minami S, Hsu SY, Chun SY, Billig H and Hsueh AJ (1997a) Preantral ovarian follicles in serum-free culture: suppression of apoptosis after activation of the cyclic guanosine 3', $5^{\prime}$-monophosphate pathway and stimulation of growth and differentiation by folliclestimulating hormone Endocrinology 138 2417-2424

McGee EA, Perlas E, LaPolt PS, Tsafriri A and Hsueh AJ (1997b) Folliclestimulating hormone enhances the development of preantral follicles in juvenile rats Biology of Reproduction 57 990-998

McGee EA, Chun SY, Lai S, He Y and Hsueh AJ (1999) Keratinocyte growth factor promotes the survival, growth, and differentiation of preantral ovarian follicles Fertility and Sterility 71 732-738

McGee EA, Smith R, Spears N, Nachtigal MW, Ingraham H and Hsueh AJ (2001) Mullerian inhibitory substance induces growth of rat preantral ovarian follicles Biology of Reproduction 64 293-298

Makrigiannakis A, Coukos G, Christofidou-Solomidou M, Montas S and 
Coutifaris C (2000) Progesterone is an autocrine/paracrine regulator of human granulosa cell survival in vitro. Annals of the New York Academy of Sciences 900 16-25

Morita Y and Tilly JL (1999) Oocyte apoptosis: like sand through an hourglass Developmental Biology 213 1-17

Mulac-Jericevic B, Mullinax RA, DeMayo FJ, Lydon JP and Conneely OM (2000) Subgroup of reproductive functions of progesterone mediated by progesterone receptor-B isoform Science 289 1751-1754

Mulac-Jericevic B, Mullinax RA and Conneely OM (2001) Phenotypic analysis of mice lacking progesterone receptor B isoform Endocrine Society's 83rd Annual Meeting (Abstract P1-67)

Murray AA, Molinek MD, Baker SJ, Kojima FN, Smith MF, Hillier SG and Spears N (2001) Role of ascorbic acid in promoting follicle integrity and survival in intact mouse ovarian follicles in vitro. Reproduction 121 89-96

Natraj U and Richards JS (1993) Hormonal regulation, localization, and functional activity of the progesterone receptor in granulosa cells of rat preovulatory follicles Endocrinology 133 761-769

Park OK and Mayo KE (1991) Transient expression of progesterone receptor messenger RNA in ovarian granulosa cells after the preovulatory luteinizing hormone surge Molecular Endocrinology 5 967-978

Peluso JJ and Pappalardo A (1998) Progesterone mediates its anti-mitogenic and anti-apoptotic actions in rat granulosa cells through a progesteronebinding protein with gamma aminobutyric acid A receptor-like features Biology of Reproduction 58 1131-1137

Press MF and Greene GL (1988) Localization of progesterone receptor with monoclonal antibodies to the human progestin receptor Endocrinology 122 1165-1175

Rannikki AS, Zhang FP and Huhtaniemi IT (1995) Ontogeny of folliclestimulating hormone receptor gene expression in the rat testis and ovary Molecular and Cellular Endocrinology 107 199-208

Reynaud K and Driancourt MA (2000) Oocyte attrition Molecular and Cellular Endocrinology 163 101-108
Robker RL, Russell DL, Espey LL, Lydon JP, O'Malley BW and Richards JS (2000) Progesterone-regulated genes in the ovulation process: ADAMTS-1 and cathepsin L proteases Proceedings National Academy of Sciences USA 97 4689-4694

Robles R, Morita Y, Mann KK, Perez GI, Yang S, Matikainen T, Sherr DH and Tilly JL (2000) The aryl hydrocarbon receptor, a basic helixloop-helix transcription factor of the PAS gene family, is required for normal ovarian germ cell dynamics in the mouse Endocrinology 141 450-453

Scaffidi C, Fulda S, Srinivasan A, Friesen C, Li F, Tomaselli KJ, Debatin KM, Krammer PH and Peter ME (1998) Two CD95 (APO-1/Fas) signaling pathways EMBO Journal 17 1675-1687

Svanberg B and Billig H (1999) Isolation of differentially expressed mRNA in ovaries after estrogen withdrawal in hypophysectomized diethylstilbestrol-treated rats: increased expression during apoptosis Journal of Endocrinology 163 309-316

Svensson PA, Johnson MS, Ling C, Carlsson LM, Billig $\mathbf{H}$ and Carlsson B (1999) Scavenger receptor class B type I in the rat ovary: possible role in high density lipoprotein cholesterol uptake and in the recognition of apoptotic granulosa cells Endocrinology 140 2494-2500

*Svensson EC, Markström E, Andersson M and Billig H (2000) Progesterone receptor-mediated inhibition of apoptosis in granulosa cells isolated from rats treated with human chorionic gonadotropin Biology of Reproduction 63 1457-1464

Talbert GB, Meyer RK and McShan WH (1951) Effect of hypophysectomy at the beginning of proestrus on maturing follicles in the ovary of the rat Endocrinology 49 687-694

*Tilly JL, Billig H, Kowalski KI and Hsueh AJ (1992) Epidermal growth factor and basic fibroblast growth factor suppress the spontaneous onset of apoptosis in cultured rat ovarian granulosa cells and follicles by a tyrosine kinase-dependent mechanism Molecular Endocrinology 6 1942-1950 